University of Nebraska - Lincoln

DigitalCommons@University of Nebraska - Lincoln

Papers in the Earth and Atmospheric Sciences

Earth and Atmospheric Sciences, Department

\title{
Stream network characteristics used to infer the distribution of fold types in the Zagros Simply Folded Belt, Iran
}

\author{
Caroline M. Burberry \\ University of Nebraska-Lincoln, cburberry2@unl.edu \\ John W. Cosgrove \\ Imperial College London, j.cosgrove@imperial.ac.uk \\ Jian Guo Liu \\ Imperial College London
}

Follow this and additional works at: https://digitalcommons.unl.edu/geosciencefacpub

Part of the Earth Sciences Commons

Burberry, Caroline M.; Cosgrove, John W.; and Liu, Jian Guo, "Stream network characteristics used to infer the distribution of fold types in the Zagros Simply Folded Belt, Iran" (2007). Papers in the Earth and Atmospheric Sciences. 291.

https://digitalcommons.unl.edu/geosciencefacpub/291

This Article is brought to you for free and open access by the Earth and Atmospheric Sciences, Department of at DigitalCommons@University of Nebraska - Lincoln. It has been accepted for inclusion in Papers in the Earth and Atmospheric Sciences by an authorized administrator of DigitalCommons@University of Nebraska - Lincoln. 


\title{
Stream network characteristics used to infer the distribution of fold types in the Zagros Simply Folded Belt, Iran
}

\author{
CAROLINE M. BURBERRY, JOHN W. COSGROVE and JIAN GUO LIU \\ Department of Earth Science and Engineering, Imperial College London, South Kensington Campus, \\ Exhibition Road, London, SW7 2AZ, UK. c.setchell@imperial.ac.uk \\ (Received 21 ${ }^{\text {st }}$ February 2007; Accepted 25 ${ }^{\text {th }}$ May 2007)
}

\begin{abstract}
Progressive deformation at a convergent margin (the Zagros Simply Folded Belt) was analysed using satellite images, digital elevation models, contour maps and artificially generated stream networks. Two end-member fold types (fault-bend folds and detachment folds) interact with streams flowing from the High Zagros Mountains into the Persian Gulf. Growing folds divert streams and create wind or water gaps in characteristic patterns which are related to the uplift histories of the two fold types. Additionally, the symmetry of minor channels reflects the inherent symmetry of the folds. The distribution of fold types is shown for the region $\mathrm{N} 27^{\circ}-\mathrm{N} 30^{\circ}$, E50 $-\mathrm{E} 54^{\circ}$ at a scale of 1:1,000,000. Anomalously long, high-aspect ratio folds, coincident with linear trends of wind gaps and topographic steps, were inferred to be fault-bend folds overlying major thrust faults. These faults formed sequentially as the deformation front migrated from the collision zone to the SW, causing diversion of stream channels. Movement up thrust ramps created these fault-bend folds and serial folding developed in the cover to the NE.
\end{abstract}




\section{Introduction}

Fold-thrust belts form the frontal regions of major contractional orogens, and are frequently important hydrocarbon provinces. In this short paper, the geometry and geomorphological attributes of the surface folds have been used to investigate the distribution of fold types within these belts. Previously, fold-thrust belts such as the Zagros Simply Folded Belt were considered to contain only detachment folds (Sattarzadeh, 1997; Vita-Finzi, 2005). However, the interaction of surface drainage systems and growing folds and measurement of geomorphic indices shows that fault-bend folds are also present, as well as a continuum of geometries between these end-member fold types. An additional significant fold geometry is that of an asymmetric detachment fold with a thrust cutting the forelimb. The distribution of detachment folds, asymmetric detachment folds and fault-bend folds can be characterised using satellite image analysis, drainage network analysis and geomorphological indicators.

The Zagros region is eminently suitable for satellite image analysis because of low vegetation coverage and well exposed outcrops in an arid climate. Therefore, structures are not obscured by vegetation and the striking fold belt of the Zagros region can be seen in great detail. The section of the belt that has been chosen for this study is in the Fars region of the Zagros Simply Folded Belt, to the east of the Kazerun fault zone (Figure 1) where the folds are capped by the Oligocene Asmari limestone (Blanc et al., 2003; McQuarrie, 2004). The sedimentary cover sequence is floored by the Hormuz Formation, a dominantly evaporite formation, which acts as a major decollement horizon (Alavi, 2004; Bahroudi and Koyi, 2003). All folds investigated in this study have been taken from this section of the belt in order to minimise any variation in deformation style caused by variations in the rheological profile of the cover succession.

Periclinal detachment folds have a characteristic amplification pattern predicted from the theoretical analyses of folding and this is reflected in the fold geometry. In regions such as the Zagros Simply Folded Belt, the geometry is reflected topographically, by concordant landform morphology. The amplification rate is found to vary both in time and space. Thus at a specific point on the fold the uplift rate will vary with time and at a particular time the uplift rate will vary along the fold hinge. As noted above, in some localities, continued shortening has been accommodated by the development of thrust faults in the forelimb, creating asymmetric 


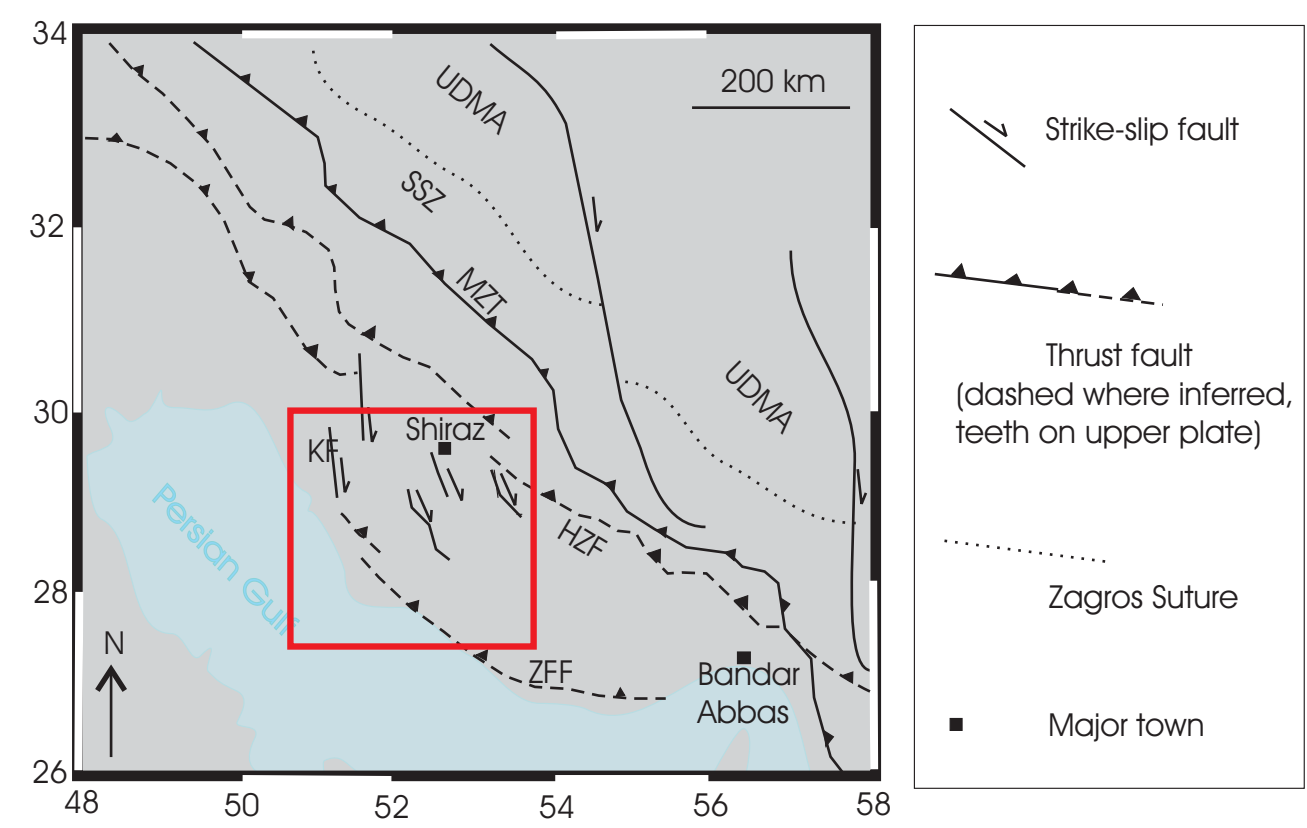

Figure 1. The setting of the Zagros Orogenic Belt (Molinaro et al., 2005). The High Zagros Fault forms the NE limit of the Simply Folded Belt, and the Zagros Frontal Fault (ZFF) marks the edge of the surface expression of deformation. UDMA, Urumieh-Dohktar Magmatic Arc; SSZ, Sanandaj-Sirjan Zone; KF, Kazerun Fault. The red box highlights the study area.

landform geometries. Fault-bend folds are formed by uniform uplift above a thrust fault at depth. Drainage systems adapt to changes in the surface slope, recording fold growth and evolution (Jackson et al., 1996). The difference in uplift rate and stream downcutting rate determines whether a wind or water gap develops on a fold. Water gaps occur where fold uplift rate is slow relative to the stream downcutting rate, generally at the end of detachment folds. Wind gaps occur where the uplift rate is higher, i.e. nearer the central point of a detachment fold, where uplift has been rapid, causing abandonment of the stream channel. In contrast, depending on the uplift rate of the underlying block beneath a fault-bend fold, the stream will either keep pace with uplift in which case water gaps will occur along the length of the fold, or the stream will be deflected, resulting in wind gaps along the fold (Burbank et al., 1999; Burbank and Pinter, 1999).

The two end-member fold types can be recognised based on characteristic drainage pattern diversions, aspect ratio, hinge length and symmetry (Figure 2). Detachment folds have low aspect ratios and near perfect symmetry, whereas fault-bend folds have high aspect ratios and a more asymmetric profile (Blanc et al., 2003; Cosgrove and Ameen, 2000; Sattarzadeh, 1997). 

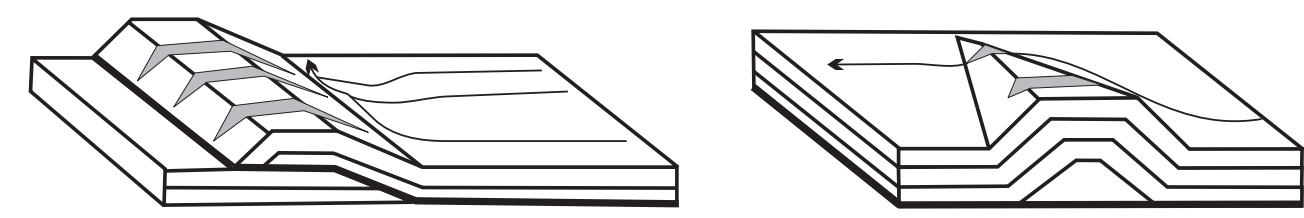

Figure 2. Two end-member fold types, showing characteristic aspect ratio, asymmetry and drainage diversion; a) detachment fold with low aspect ratio and short hinge length showing a wind gap in the centre of the structure and a water gap at the end, and b) fault-bend fold with a high aspect ratio and long hinge length showing wind gaps and defeated streams diverted parallel to the fold hinge line.

\section{Methods}

Satellite images were used to delimit fold shapes and to mark locations and diversions of the stream network. Colour composites were created by combining Landsat ETM+ bands 5, 3, 1 as red, green and blue (Figure 3), which highlights variation in lithology, and suppresses vegetation (Drury, 2001). Colours were balanced using the balanced contrast enhancement technique (Liu, 1991). Carbonate layers appear in pink, here picking out the folds which are capped by the Asmari limestone. The top of the Asmari limestone has been delimited on each image and fold axial traces were identified from the closures of this marker. Major stream channels have also been identified. In areas of confusion, the concentration of vegetation around streams visible on a 432-RGB image was used to separate stream beds from other features. In order to clarify the relationship between lithology and topography and to identify wind and water gaps in the folds, the enhanced satellite images were draped over a digital elevation model (tiles from the Shuttle Radar Topography Mission - SRTM) covering the area $\mathrm{N} 27^{\circ}-\mathrm{N} 30^{\circ}, \mathrm{E} 51^{\circ}-\mathrm{E} 54^{\circ}$.

Mio-Pliocene (Molinaro et al., 2005) folding in the Zagros Simply Folded Belt has altered the drainage network by defeating and diverting streams. To investigate this, an artificial stream network was generated from the SRTM tiles, where streams were categorised by the Strahler system (Strahler, 1964). The stream network is a good substitute indicator of the landform organisation and the density of the lowest order streams delimits the landforms clearly (Cudennec and Fouad, 2006). The artificially generated stream network was compared to the manually picked network. Errors occurred in the region of namakirs (salt glaciers) where the software generating the artificial network interpreted the relative topographic low as a stream channel. Once this comparison was completed, a map of the 


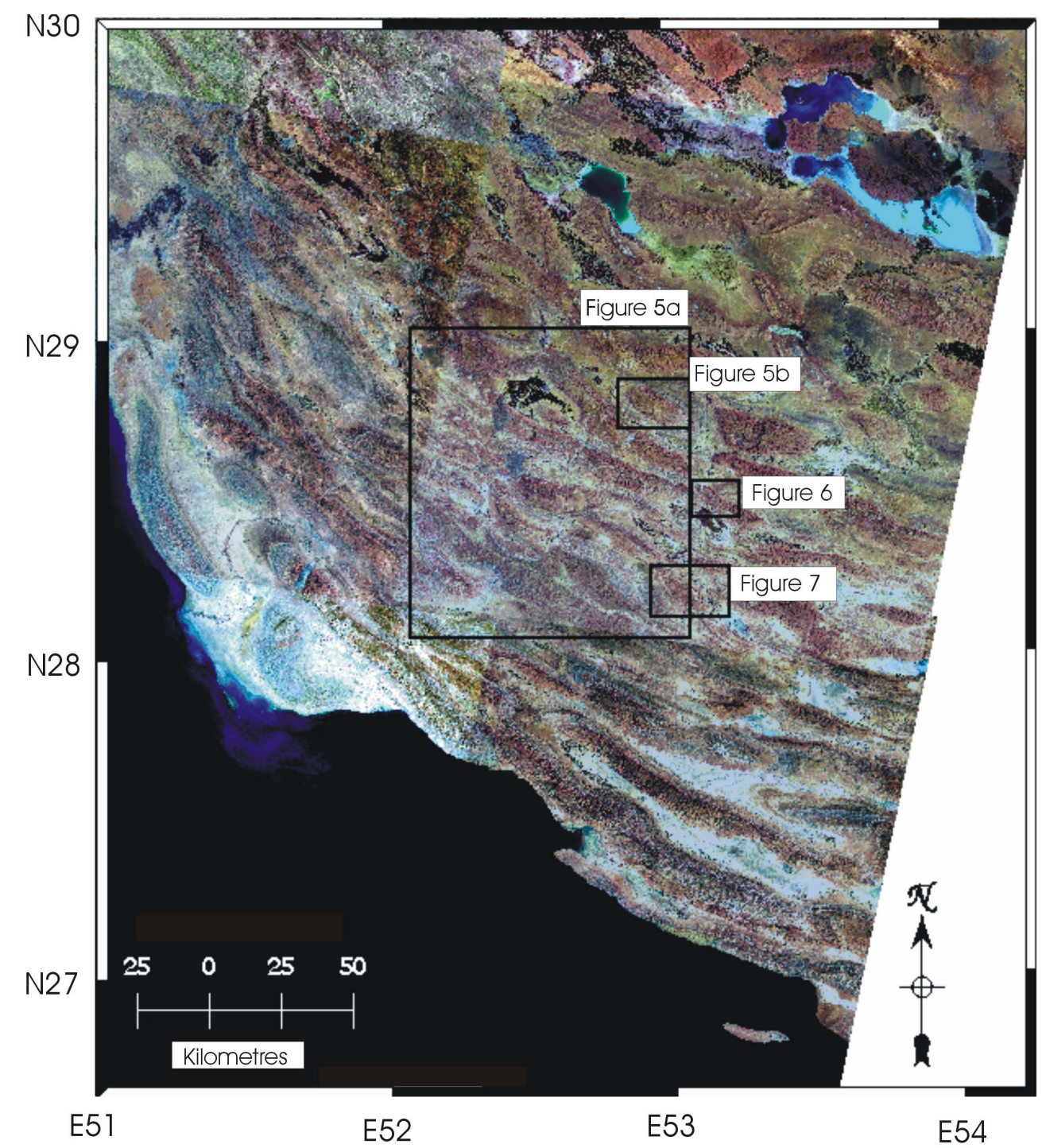

Figure 3. Mosaic of colour composites of the study area within the Zagros Simply Folded Belt $\left(\mathrm{N} 27^{\circ}-\mathrm{N} 30^{\circ}, \mathrm{E} 51^{\circ}-\mathrm{E} 54^{\circ}\right)$. The image has been enhanced to highlight lithological variations and suppress vegetation. The Asmari limestone caps the folds and can be seen in pink. Folds falling in the white area were not used in this study and are marked grey on the main map.

locations of stream diversions and abandoned channels was generated.

Folds identified from satellite image analysis were categorised using geomorphic indices (Figure 4) calculated from fold width, hinge length and forelimb width measured off a base contour map. This map was generated from the SRTM tiles. Both aspect ratio (hinge length: fold width) and fold symmetry index (width of forelimb: half width) can be used to separate 
fold types and were calculated for each fold.

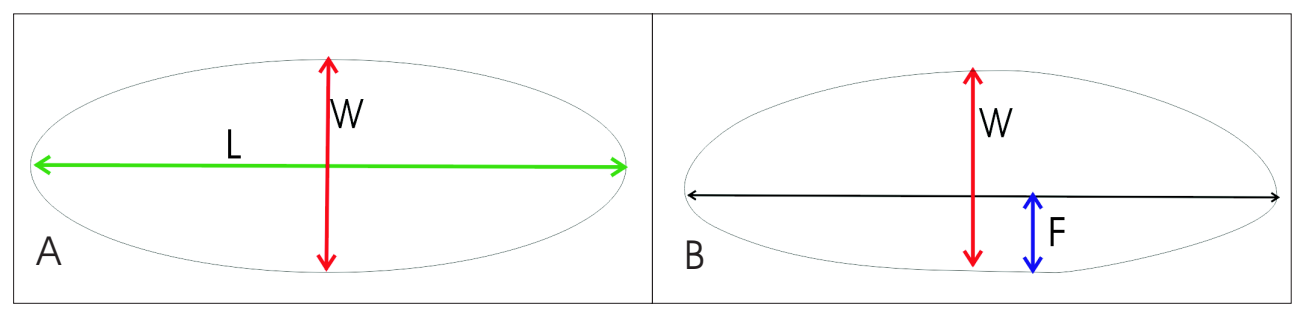

Figure 4. Geomorphic indices used to differentiate fold types; a) aspect ratio (L/W) and b) fold symmetry index $(2 \mathrm{~F} / \mathrm{W})$.

\section{The drainage system and drainage diversion}

The pre-folding drainage system is likely to have been a dendritic system (Summerfield, 1991) with the dominant direction of flow approximately from NE to SW i.e. towards the Persian Gulf. Present-day higher order streams show a deviation from the dendritic pattern to a trellis pattern, with the prominent stream direction parallel to the NW-SE trending fold hinges (Figure 5a). Individual fold shapes are delimited by lower order streams. Symmetric stream network patterns are taken as representative of detachment folds (Figure 5b) and asymmetric stream network patterns are found across fault-bend folds.

Water gaps (Figure 6) where the stream has cut through the end of the growing fold, and wind gaps (Figure 7) where the stream system has been defeated and diverted around the growing fold, were identified by comparing satellite images and the artificial stream network. In map view, both wind and water gaps occur in linear trends, parallel to the fold axial traces. These linear trends of wind and water gaps mark distinct episodes of folding, and coincide with anomalously long folds interpreted to be fault-bend folds. 


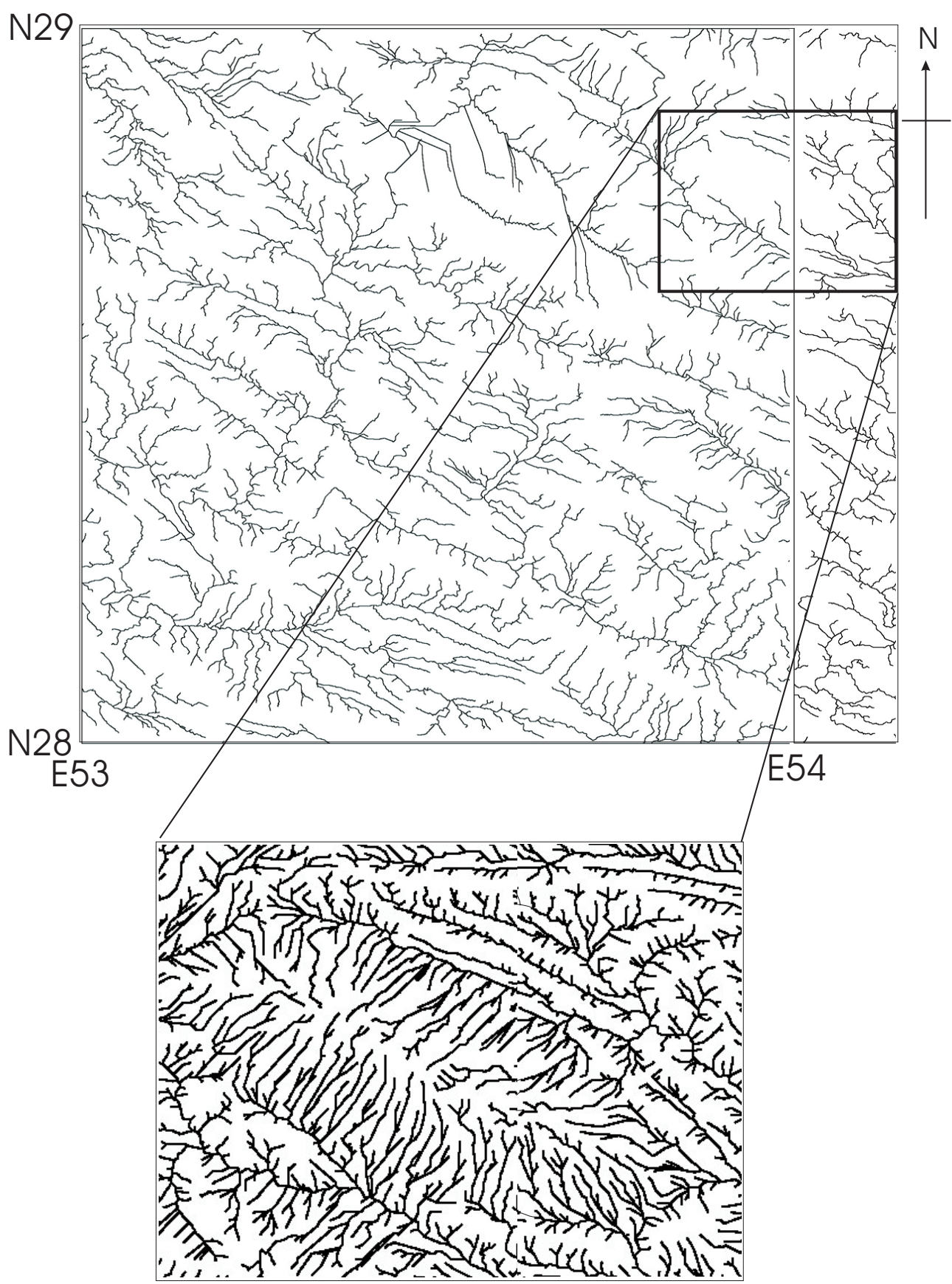

Figure 5. Drainage patterns in the Zagros simply folded belt; a) high order streams displaying a trellis pattern with the prominent direction paralleling the fold hinge lines and b) low order streams showing a symmetrical pattern around a detachment fold. 

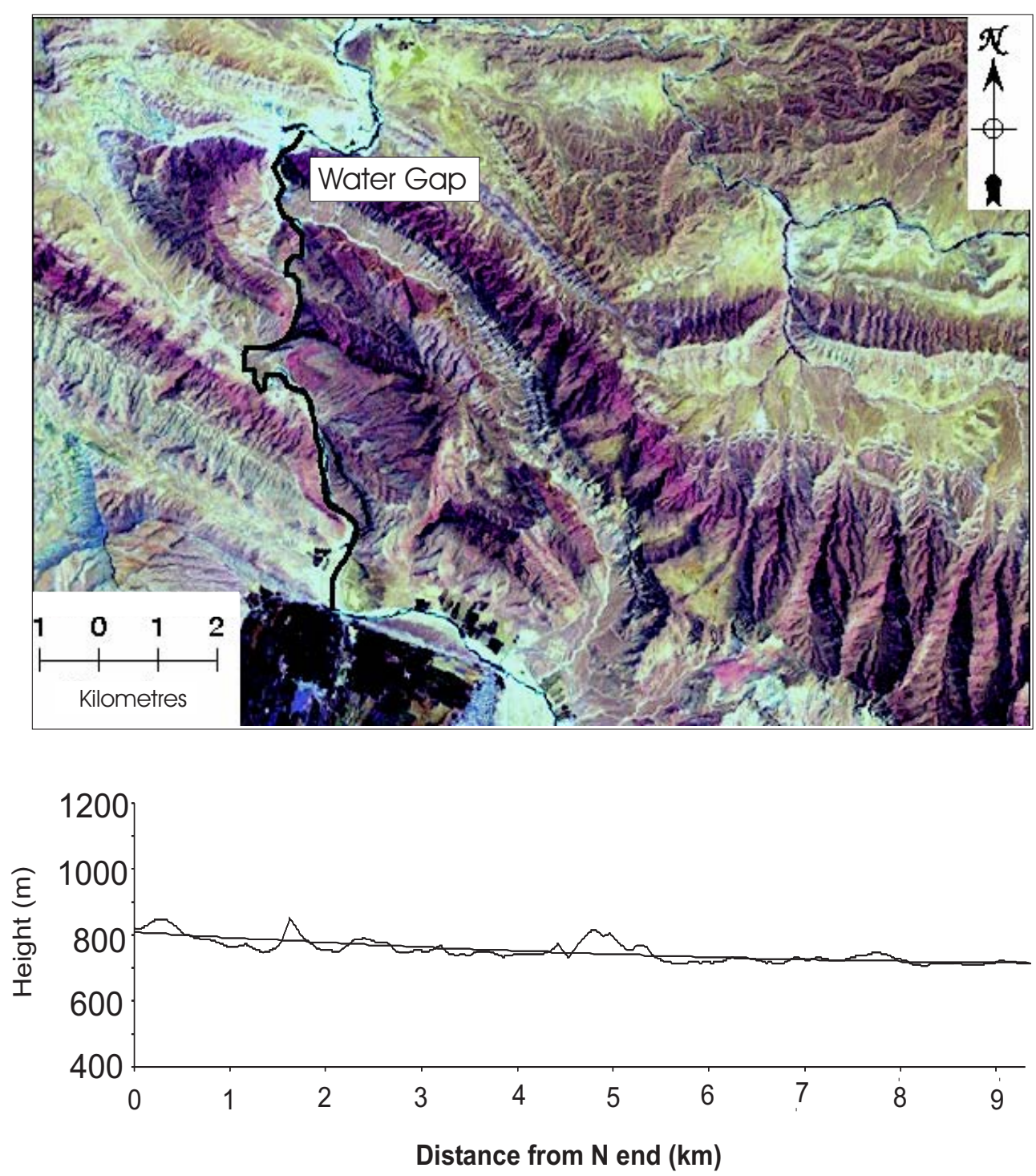

Figure 6. A characteristic water gap on an enhanced image (top) and in topographic profile (bottom), showing a concave profile, and cutting through the end of a fold. Vertical exaggeration $\sim \mathrm{x} 3$.

\section{Geomorphic Indices}

Detachment and fault-bend folds are clearly distinguished by the variation in aspect ratio with fold hinge length. Fold symmetry also varies with hinge length, and detachment folds and fault-bend folds can be distinguished. A number of folds with opposite vergence (NE) to that of the majority of folds in the belt (SW) as well as a set of folds with a shorter hinge length 
than fault-bend folds but a lower symmetry than detachment folds are observed. These are interpreted to be detachment folds that have become asymmetric as a result of thrust faults cutting the forelimbs to accommodate shortening (McQuarrie, 2004; Sepehr and Cosgrove, 2006; Sherkati and Letouzey, 2004; Sherkati et al., 2005).

Folds with the longest hinge lines and high aspect ratios are also asymmetric, supporting the conclusion that these folds are fault-bend folds. However, scatter is seen in the dataset, relating in part to the influence of surface processes. For folds where there is an independent field dataset of structural dips, the symmetry is shown to be consistently overestimated by about $5 \%$, that is, landform symmetry is higher (fold symmetry index closer to 1) than the symmetry of the dipping beds. This implies that, despite the influence of surface processes, the observed variation in fold symmetry index can still be used as an indicator of fold type.
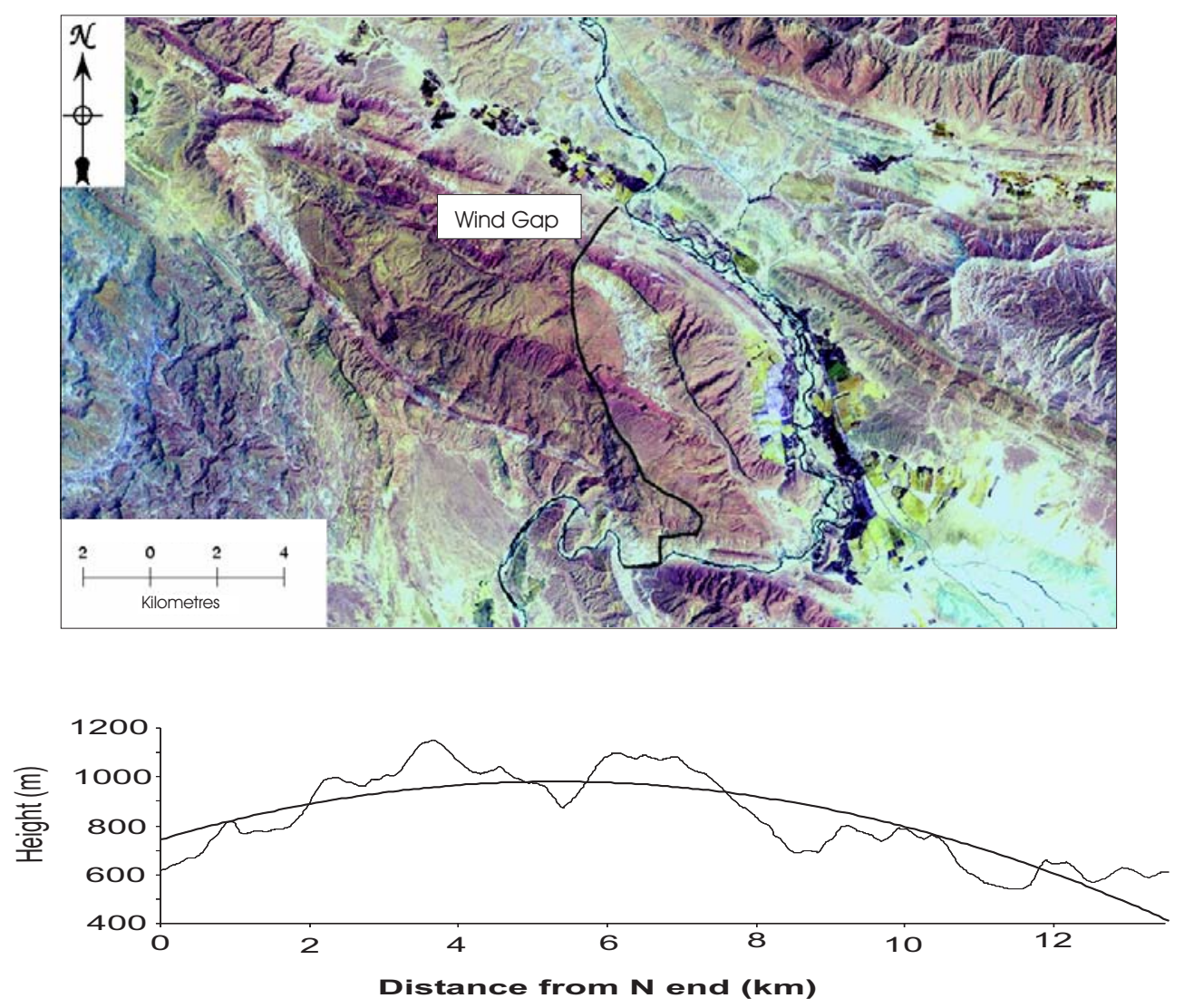

Figure 7. A characteristic wind gap, on an enhanced image (top) and in topographic profile (bottom) showing a convex profile, cutting across a fold. Vertical exaggeration $\sim \mathrm{x} 3$. 


\section{Map Generation}

Each fold was classified using the geomorphic indices discussed above, together with the locations of wind and water gaps. Folds with short hinge lengths and low aspect ratios were found to correlate with the locations of diverted streams and were inferred to be detachment folds. However, the spatial coincidence of linear trends of wind gaps parallel to the fold hinge lines, major stream diversions and long, high aspect ratio, asymmetric folds (Figure 8) implies that these are fault-bend folds.

The majority of folds in this fold-thrust belt are detachment folds, but the location of fault-bend folds is a crucial indicator of the presence of major thrust faults. In the Zagros Simply Folded Belt, the fault-bend folds are spatially related to the locations of the known major thrust faults, the High Zagros Fault, Mountain Front Fault and Zagros Frontal Fault. Detachment folds are found to the NE of the fault-bend folds, in the hangingwall of the thrust faults. Some detachment folds are asymmetric, implying that continued shortening has led to thrusting in the forelimb of these folds. The location of individual folds, coloured according to type, has been displayed in the accompanying map.

\section{Conclusions}

The resulting map indicates that the different fold types are found in predictable locations in a fold-thrust belt and that these locations can be identified using remote sensing methods. Fault-bend folds form spatially associated with the major thrust faults. It is suggested that the faults formed sequentially as the deformation front migrated to the SW.

Movement up thrust ramps created these fault-bend folds and subsequently, detachment folds developed in the cover to the NE by serial folding. The presence of asymmetric, detachment folds implies that additional shortening may have been accommodated by thrust development in the core of detachment folds. 


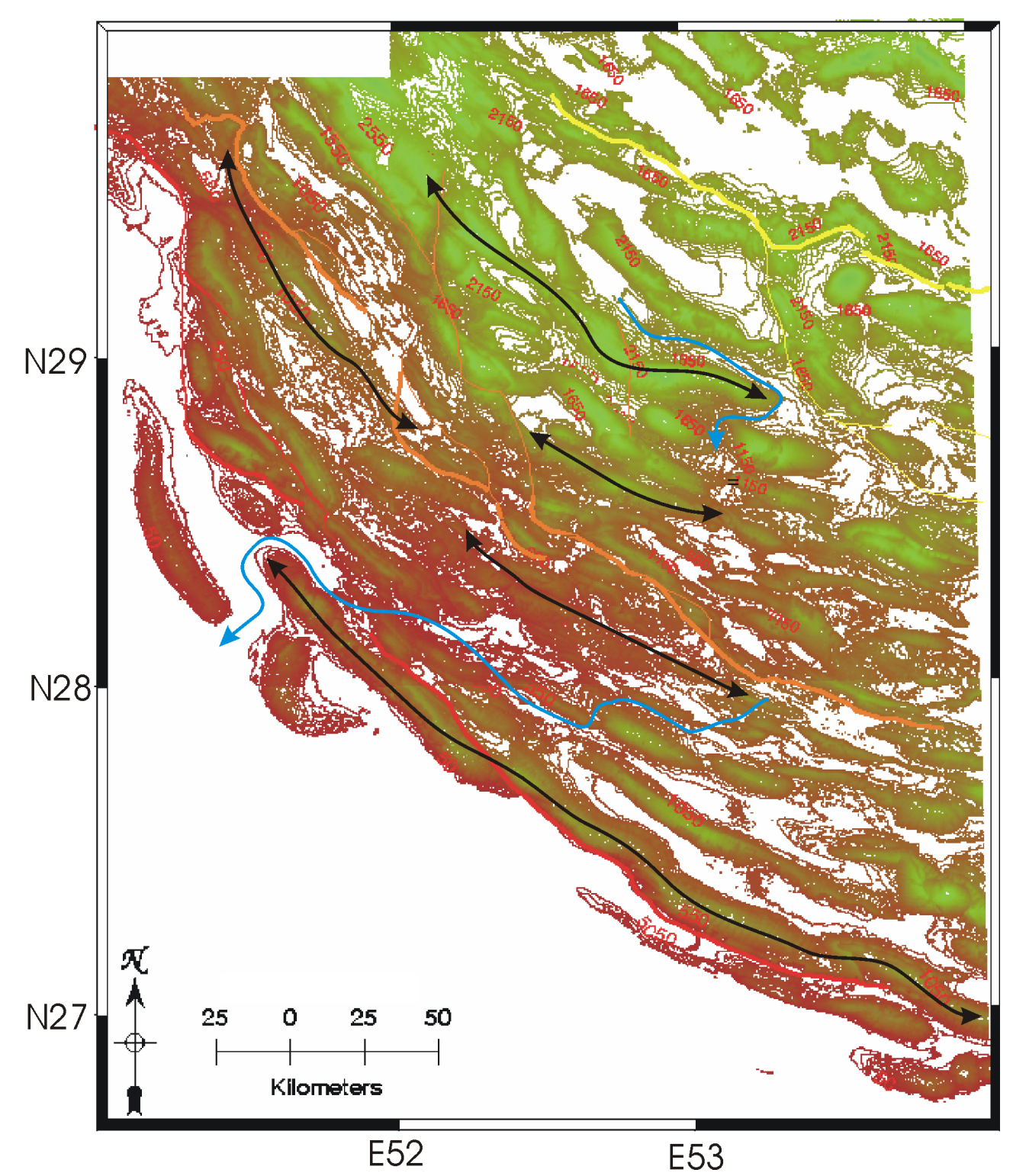

Figure 8. Composite map showing the spatial relationships between major stream diversions, trends of wind gaps (black) and the major thrust faults. The wind gap trends parallel the hinge lines of long, high aspect ratio folds which are spatially associated with major thrust faults. Detachment folds are found between the three major thrust faults.

\section{Software}

The map was produced using satellite image processing (in ER Mapper) and processing of DEM files to generate the base contour maps. The stream network, including wind and water gaps, was created by systematic 
examination of satellite data, DEM data and an artificial stream network generated using RiverTools (MIMAS). Geomorphic indices were measured from the contour maps using Didger (Golden Software Inc.). The final map outline was drawn in ERMapper and edited in CorelDraw.

\section{Data Sources}

Satellite data used in this study was sourced from the Global Landcover Facility, www.landcover.org. The following datasets were used:

NASA Landsat Program, 2004, Landsat ETM+ scene 038_075, GeoCover, USGS, Sioux Falls, 17/05/2000; NASA Landsat Program, 2004, Landsat ETM+ scene 038_076, GeoCover, USGS, Sioux Falls, 17/05/2000; NASA Landsat Program, 2004, Landsat ETM+ scene 038_077, GeoCover, USGS, Sioux Falls, 15/04/2000; NASA Landsat Program, 200*, Landsat ETM+ scene 038_127, GeoCover, USGS, Sioux Falls, 08/05/2000; NASA Landsat Program, 2004, Landsat ETM+ scene 038_128, GeoCover, USGS, Sioux Falls, 22/04/2000; NASA Landsat Program, 2004, Landsat ETM+ scene 038_129, GeoCover, USGS, Sioux Falls, 22/04/2000.

The DEM tiles used in this study were sourced from the NASA Land Processes Distributed Active Archive Centre (ftp://e0srp01u.ecs.nasa.gov/srtm/). Research grade data from the second processing stage of the Shuttle Radar Tomography Mission (Version

2) were downloaded, covering the area $\mathrm{N} 27^{\circ}-\mathrm{N} 30^{\circ}, \mathrm{E} 51^{\circ}-\mathrm{E} 54^{\circ}$.

\section{Acknowledgements}

This research was supported by a Janet Watson Scholarship from the Department of Earth Science and Engineering, Imperial College London. 


\section{References}

ALAVI, M. (2004) Regional stratigraphy of the Zagros fold-thrust belt of Iran and its proforeland evolution, American Journal of Science, 304, $1-20$.

BAHROUDI, A. and KOYI, H. A. (2003) Effect of spatial distribution of Hormuz salt on deformation style in the Zagros fold and thrust belt: an analogue modelling approach, Journal of the Geological Society, 160, 719-733.

BLANC, E. J. P., ALLAN, M., INGER, S. and HASSANI, H. (2003) Structural styles in the Zagros Simple Folded Zone, Iran, Journal of the Geological Society, 160, 401-412.

BURBANK, D. W., MCLEAN, J., BULLEN, M., ABDRAKHMATOV, K. and MILLER, M. (1999) Partitioning of intermontane basins by thrust-related folding, Tien Shan, Kyrgyzstan, Basin Research, 11, 75-9.

BURBANK, D. W. and PINTER, N. (1999) Landscape evolution: the interactions of tectonics and surface processe, Basin Research, 11, 1-6.

COSGROVE, J. and AMEEN, M. (2000) A comparison of the geometry, spatial organisation and fracture patterns associated with forced folds and buckle folds, Geological Society of London Special Publication, 169, 7-21.

CUDENNEC, C. and FOUAD, Y. (2006) Structural patterns in river network organization at both infra- and supra-basin levels: the case of a granitic relief, Earth Surface Processes and Landforms, 31, 369-381.

DRURY, S. (2001) Image interpretation in Geology, Nelson Thornes Ltd, Cheltenham, 290 pp.

JACKSON, J., NORRIS, R. and YOUNGSON, J. (1996) The structural evolution of active fault and fold systems in central Otago, New Zealand: Evidence revealed by drainage patterns, Journal of Structural Geology, 18, 217-234.

LIU, J. G. (1991) Digital image processing for automatic lithological mapping using Landsat TM imagery, Ph.D. thesis, Imperial College, London. 
MCQUARRIE, N. (2004) Crustal scale geometry of the Zagros fold-thrust belt, Iran, Journal of Structural Geology, 26, 519-535.

MOLinARO, M., LETURMY, P., GUEZOU, J., DE LAMOTTE, D. and ESHRAGHI, S. (2005) The structure and kinematics of the southeastern Zagros fold-thrust belt, Iran: From thin-skinned to thick-skinned tectonics, Tectonics, 24, TC3007.

SATTARZADEH, Y. (1997) Active Tectonics in the Zagros Mountains, Iran, Ph.D. thesis, Imperial College, London.

SEPEHR, M. and COSGROVE, J. W. (2006) The impact of cover rock rheology on the style of folding in the Zagros fold-thrust belt, Tectonophysics, 427, 265-28.

SHERKATI, S. and LETOUZEY, J. (2004) Variation of structural style and basin evolution in the central Zagros (Izeh zone and Dezful Embayment), Iran, Marine and Petroleum Geology, 21, 535-554.

SHERKATI, S., MOLINARO, M., DE LAMOTTE, D. and LETOUZEY, J. (2005) Detachment folding in the Central and Eastern Zagros fold-belt (Iran): salt mobility, multiple detachments and late basement contro, Journal of Structural Geology, 27, 1680-1696.

STRAHLER, A. N. (1964) Quantitative geomorphology of drainage basins and channel networks, In Handbook of Applied Hydrology (Ed., CHOW, V. T.), McGraw-Hill, New York.

SUMMERFIELD, M. A. (1991) Global Geomorphology, Prentice Hall, Harlow, 537 pp.

VITA-FINZI, C. (2005) Serial Deformation, Proceedings of the Geologists' Associatiom, 116, 293-300. 


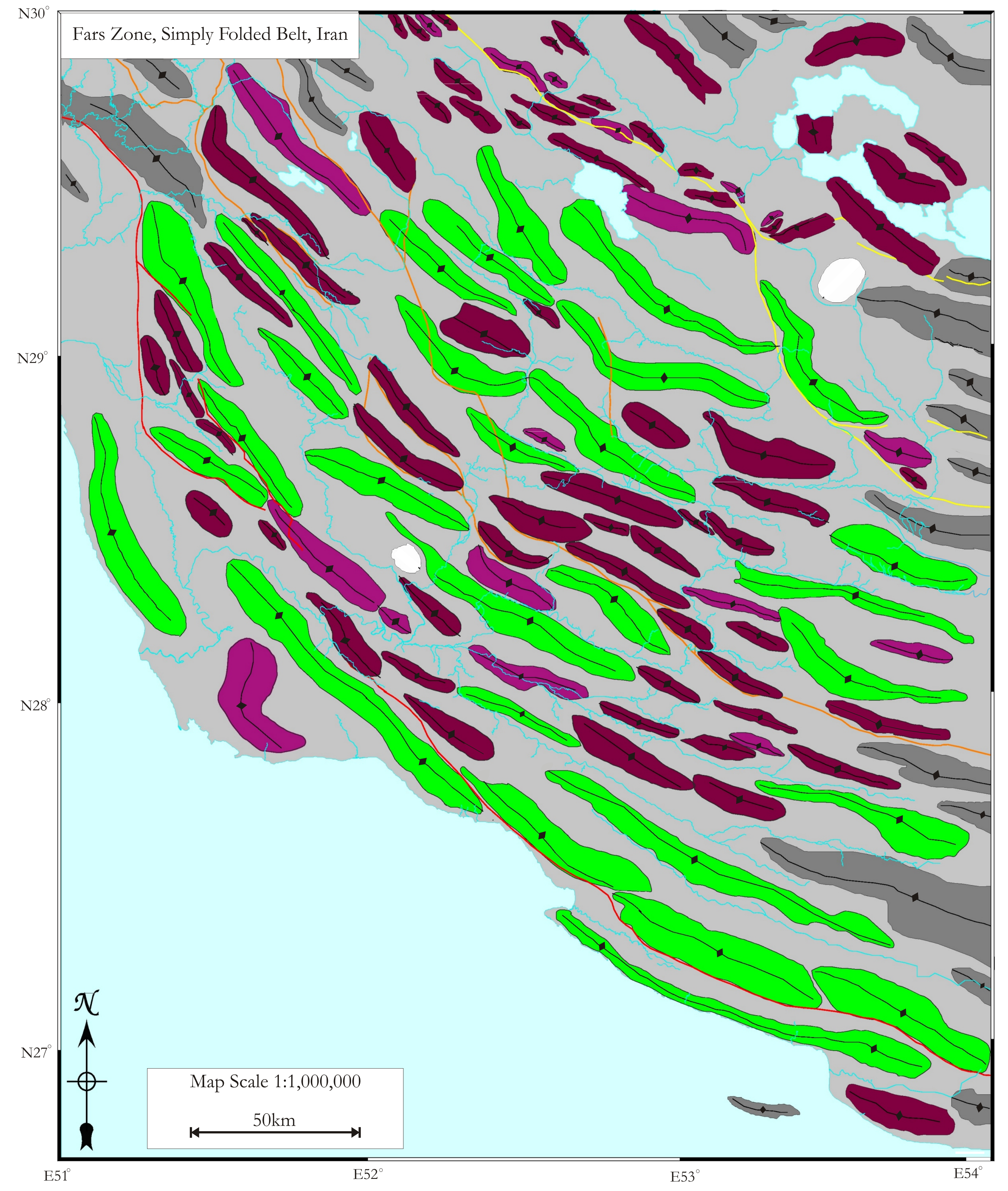

The Distribution of Fold Types in the Zagros Simply Folded Belt, Iran

C. M. Setchell, J.W. Cosgrove \& J-G Liu; Imperial College London

This map illustrates the distribution of fold types within the Zagros Simply Folded Belt. A limited amount of other structural data is displayed.

The map was created using satellite data from the Global Land Cover Facility (University of Maryland) and Digital Elevation data from the USGS Shuttle Radar Topography Mission. The satellite data is orthorectified by the provider, using the datum WGS 84 and UTM zone 39. This map uses the same projection. The horizontal resolution of the satellite data is $28.5 \mathrm{~m}$ and the vertical resolution of the Digital Elevation Model is $30 \mathrm{~m}$.

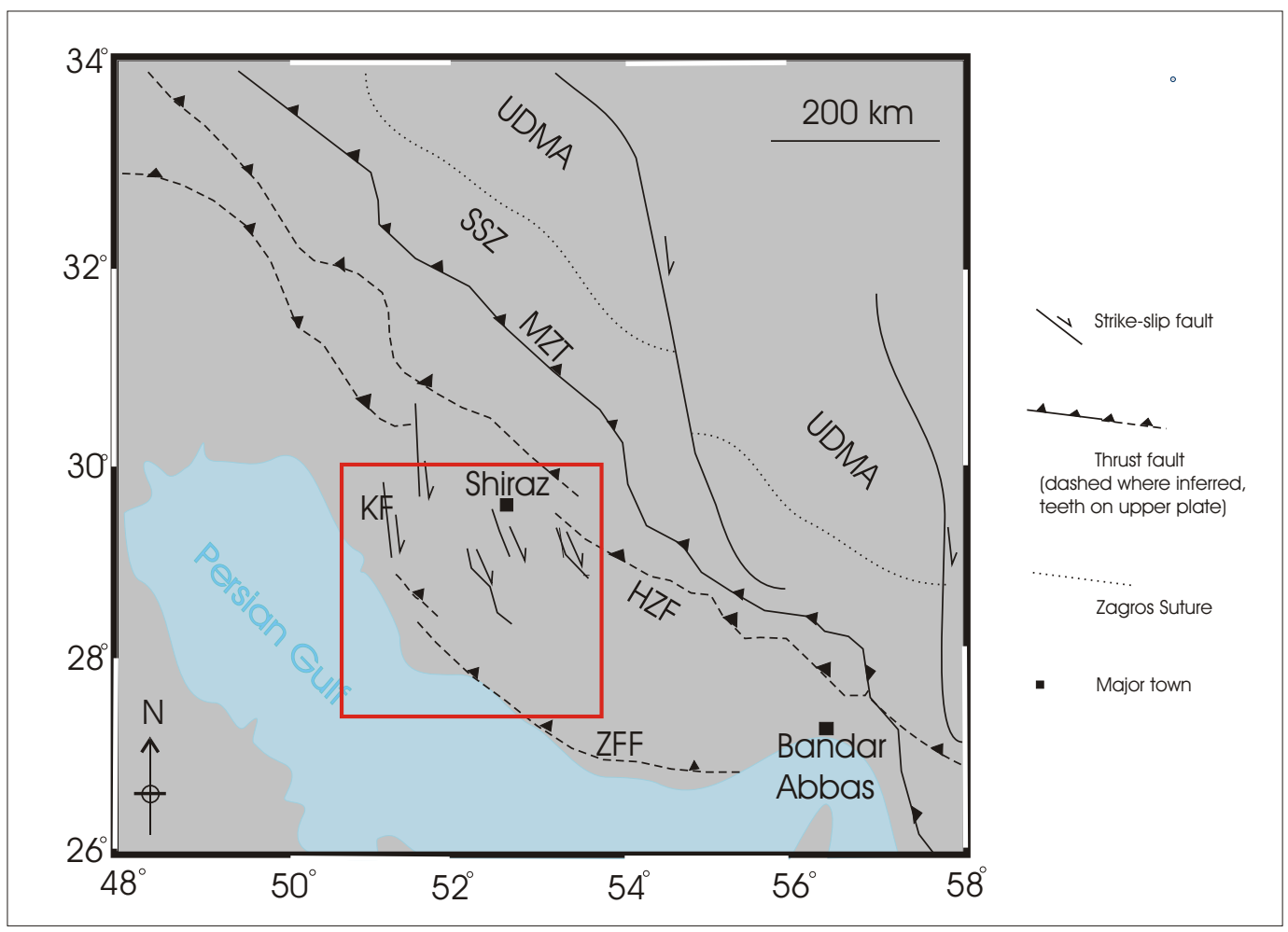

Location of the map within the Zagros Simply Folded Belt, Iran

Key

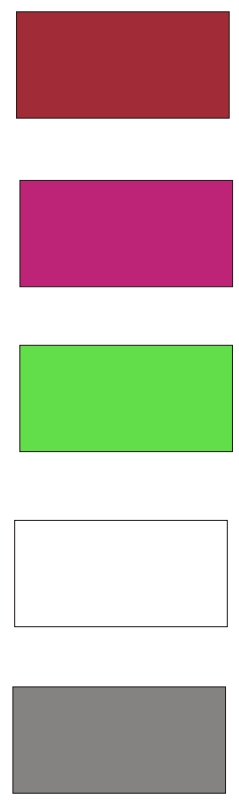

Detachment fold

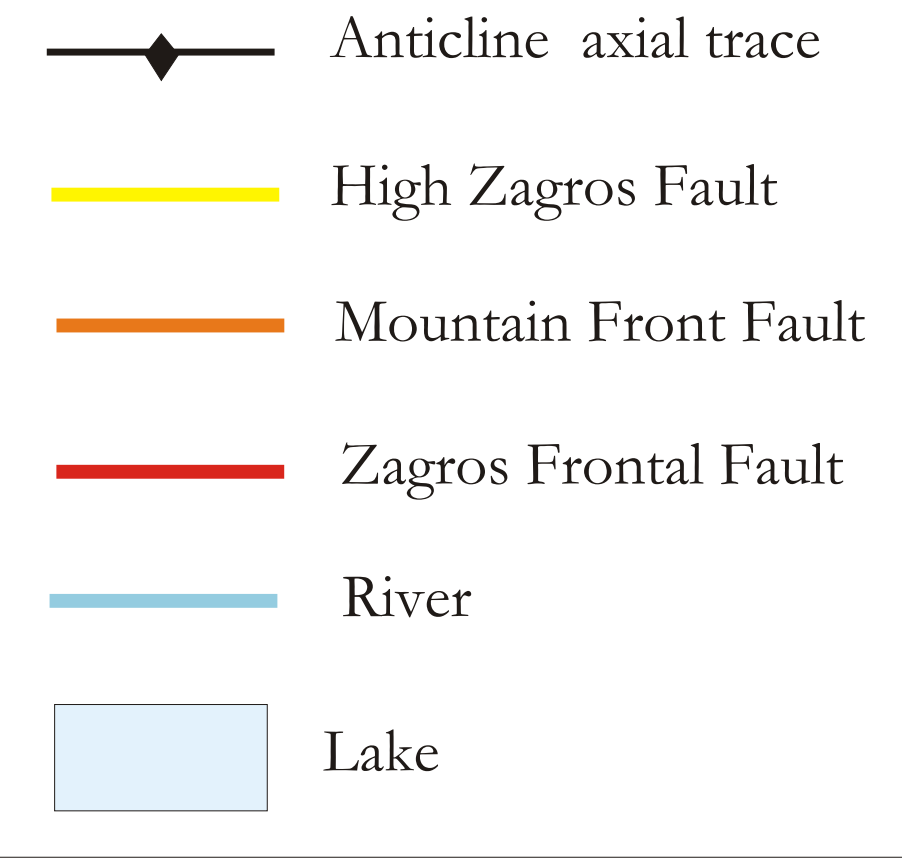

Asymmetric detachment fold

Fault-bend fold

Salt dome

Fold not used in this study 